\title{
Insulin resistance and inflammation in an evolutionary perspective: the contribution of cytokine genotype/phenotype to thriftiness
}

\author{
J.-M.Fernández-Real, W. Ricart \\ Diabetes Unit, Endocrinology and Nutrition, University Hospital of Girona “Dr Josep Trueta”, Girona, Spain
}

\section{Abstract}

Aims/hypothesis. To describe a unifying hypothesis of the relation between insulin resistance and inflammatory response in the development of diabetes.

Methods. Review of the literature and authors' research.

Results. Infection and injury activate the immune system and bring about widespread metabolic changes which disavantatge and destroy the invading organism and facilitate repair of damaged tissue. Tumour necrosis factor- $\alpha$ is involved in inflammatory events and fight against infection. No study has extensively investigated its numerous metabolic effects. From induction of hyperlipidaemia to regulation of intracellular insulin signalling, TNF- $\alpha$ has been even associated with nutrient-sensing pathways. Certain $T N F-\alpha$ gene polymorphisms (linked to a high transcription rate of TNF- $\alpha$ ), and the plasma concentrations of the TNF- $\alpha$ soluble receptor are simultaneously associated with insulin resistance, body fat, and with mortality after chronic infections. Thus, the TNF system seems to be designed for an effective fight against in- fection and for providing survival advantages during periods of food shortage. By inducing muscle insulin resistance, the energetic substrates are safeguarded for brain metabolism.

Conclusion/interpretation. In the presence of an insulin resistance genotype and westernisation (high carbohydrate diet, increased saturated fat, low fibre and sedentary habit), a high cytokine responder genotype would be prone to deterioration of insulin resistance and, finally, to Type II (non-insulin-dependent) diabetes mellitus and atherosclerosis. For our ancestors, the advantages of a high cytokine responder (eradication of injury) or moderate insulin resistance (protection against starvation) overcame the possible inconveniences of atherosclerosis. We propose that the latter are good adaptations to the environment or "maladaptations" of actual lifestyle to our genome. [Diabetologia (1999) 42: 1367-1374]

Keywords TNF- $\alpha$, TNF- $\alpha$ receptor, cytokine, insulin resistance, obesity, leptin, Type II diabetes mellitus, thrifty genotype.

\section{Overview}

Some authors believe there has been little change in the human gene pool since the appearance of Homo sapiens sapiens about 30000 years ago [1,2]. Modern humans are still genetically adapted to a pre-agricul-

Received: 4 March 1999 and in revised form: 11 June 1999

Corresponding author: J.M. Fernández-Real, MD, PhD, Unitat de Diabetes, Endocrinologia i Nutrició. Hospital de Girona, Ctra. França s/n, 17007 Girona, Spain tural hunter-gatherer lifestyle. This lifestyle involved a great deal of physical activity, coupled with a diet high in protein and low in fat. There were probably frequent periods of famine [3]. Thus, it is likely that many metabolic features of modern humans originally evolved as an adaptation to such a lifestyle. Recently it has been speculated that impaired glucose tolerance and Type II (non-insulin-dependent) diabetes mellitus constitute maladaptations of the normal innate immune system response to environmental threats [4]. According to this hypothesis, some people would be genetically or innately imbued with an in- 
creased stress response and would be prone to develop Type II diabetes [4]. The "disease of the innate immune system" might have alternative explanations. Our hypothesis is that inflammation could be intrinsic to insulin resistance and Type II diabetes mellitus and that environmental conditions determine the beneficial or adverse effects of this "proinflammatory" genotype.

\section{The prolonged acute phase response as a consequence of insulin resistance}

Infection and injury activate the immune system and bring about widespread metabolic changes which disavantage and destroy the invading organism and facilitate repair of damaged tissue. The production of cytokines and oxidant molecules is part of a highly effective mechanism for creating a hostile environment for pathogens within the body [5]. The poor prognosis and the poor wound healing of malnourished patients who have a reduced ability to produce cytokines indicate the essential nature of cytokines in recovery from infection and trauma [6].

A tendency towards increased secretion of cytokines could be beneficial in some situations such as acute infection and trauma. We must remember that the rate of endemic infectious disease (especially parasitism) and the prevalence of post-traumatic disability were all far higher 25000 years ago than they are now and constituted the chief causes of mortality from the Paeleolithic era until the 20th century [3]. On the other hand, the intake of the Stone Age hunter-gatherers could sometimes have equalled that of modern humans but at other times of the year it would have been minimal. We still carry their inheritance genes selected for their way of life. Thus, in the presence of intermittent intakes, it would be beneficial to select those genes that imply the best defence against infection and trauma with minimal caloric intake. Monocytes taken from obese patients, that received $420 \mathrm{~kJ} /$ day for 6 days, have shown a threefold increase in the ability to produce TNF- $\alpha$ in response to phytohaemagglutinin or endotoxin stimulation in vitro compared with the response before diet restriction [7]. Another indirect piece of evidence that suggests that our genome is designed to fight against infection with minimal food intakes is that enhanced mortalities have been noted in malnourished, infected populations once nutritional supplementation is commenced [8]. In this respect, cytokine-induced anorexia of severe trauma and infection could be an attempt to selectively avoid nutrients that might disadvantage the response of the host to pathogens [9].

Insulin resistance is the main condition associated with many of the features of Type II diabetes and the insulin resistance syndrome, including dyslipidaemia, hypertension, abdominal obesity, hypergly- caemia and atherosclerosis [10]. We propose that insulin resistance is pivotal in the cytokine-associated, acute-phase reaction of Type II diabetes. Serum sialic acid concentration, an acute-phase marker, is raised in Type II diabetes but is not changed in uncomplicated Type I (insulin-dependent) diabetes mellitus of similar age and glycaemic control [11,12]. This was interpreted as liver insulin resistance being much more prominent in Type II diabetes or insulin having a relatively minor role in the regulation of the response [4]. We do not agree with the last part of this interpretation. Insulin inhibits acute-phase protein synthesis in animal and human hepatoma cell lines [13]. The liver is the principal target of systemic inflammatory mediators and is also the organ responsible for determining the level of essential metabolites provided to the organism during the critical stages of stress. We (in collaboration with Dr Pugeat's group) have recently shown that insulin might regulate the synthesis of a liver protein closely involved in inflammatory events, cortisol binding globulin (CBG) [14].

Liver cells respond to many of the factors through their cell-surface receptors. According to one argument [15], the inflammatory mediators fall into four major categories: (1) interleukin (IL)-6 type cytokines, of which IL-6 is the major representative; (2) IL-1 type cytokines (including IL- $1 \alpha$, IL- $1 \beta$, tumour necrosis factor (TNF)- $\alpha$ and TNF- $\beta$ ); (3) glucocorticoids; and [4] growth factors (including insulin). The cytokines would act as primary stimulators of acutephase protein (APP) gene expression, whereas the glucocorticoids and growth factors function more as modulators of cytokine action. Insulin attenuates IL1-type and IL-6-type cytokine stimulation of most $A P P$ genes in human hepatoma cells [13]. Thus, the lack of sufficient insulin action, as found in Type II diabetes, or unsubstituted insulin deficiency would not be able to block TNF, IL-1 and IL-6 actions, leading to prolonged acute-phase reaction.

The "disease of the innate immune system" might thus be viewed as a consequence of insulin resistance and intracellular glucopenia. In different situations of insulin resistance, cytokines are up regulated. Firstly, note the influence of obesity itself on innate and adaptative immunity. In one study of 116 obese subjects (BMI $33.2 \pm 0.6 \mathrm{~kg} / \mathrm{m}^{2}$ ) it was found that obesity is related to increased leucocyte and lymphocyte subset counts and higher monocyte and granulocyte phagocytosis and oxidative burst activity [16]. Diet restriction (an actual equivalent to periods of famine of our ancestors) is a well-known inducer of insulin resistance [17]. On the other hand, prenatal exposure to protein restriction seems to programme insulin resistance in later adult life [18-19].

Secondly, strenuous exercise is another situation of insulin resistance [20] and a model of the acute-phase response. The cytokine response to strenous exercise can be viewed as a model of the cytokine response to 
sepsis and trauma [21]. The influence of carbohydrate ingestion on immune function after prolonged and intensive exertion has been evaluated in a recent study. Carbohydrate relative to placebo ingestion was associated with higher plasma concentrations of glucose and insulin, lower plasma cortisol and a diminished perturbation in blood immune cell counts, lower natural killer-cell activity and lower IL-6 [22]. These data suggest that carbohydrate ingestion, possibly by improving intracellular glucopenia during prolonged endurance exercise, can help to lessen the stress on the immune system and attenuate cytokine concentrations in the inflammatory cascade. In relation with these events, we have shown lower cortisol concentrations after oral glucose in subjects with abdominal obesity and insulin resistance in a basal, nonstressed environment [23].

Thirdly, ageing is usually associated with increased insulin resistance [24]. The production of circulating acute-phase proteins [25], the secretion of cytokines from monocyte and macrophages [26] and the soluble fraction of TNF- $\alpha$ receptor 2 [27] are all increased with age.

\section{The role of TNF}

There is evidence that TNF- $\alpha$ has a key role in mediating insulin resistance as a result of obesity [28-34]. In obese humans [32-34] and numerous rodent models [28-31] of obesity-diabetes syndromes, TNF- $\alpha$ is overexpressed in the adipose and muscle tissues compared with tissues from lean individuals. Tumour necrosis factor- $\alpha$ blocks the action of insulin in cultured cells and whole animals [28-30]. The induction of insulin resistance is mediated through its ability to produce serine phosphorylation of insulin-receptor-substrate-1 (IRS-1), decreasing the tyrosine kinase activity of the insulin receptor [30]. Neutralisation of TNF- $\alpha$ in obese $f a / f a$ rats, by intravenous injection of a soluble TNF receptor-immunoglobulin G chimeric protein, substantially improved insulin sensitivity and restored the tyrosine kinase activity in fat and muscle $[28,30]$. It also reverted the insulin-induced phosphorylation of IRS-1 to that observed in lean animals [30]. In contrast, treatment of Type II diabetic human subjects with an antibody specific for TNF had no effect on insulin sensitivity [35]. In this study, however, a single dose of antibody was given to adults with established diabetes. Probably, this approach does not affect the autocrine and paracrine effect of TNF- $\alpha$. Recent studies showed that mice lacking expression of TNF ligand, with a targeted zero mutation in the gene encoding TNF- $\alpha$, were spared from obesity-induced deficiencies in insulin-receptor signalling in fat and muscle tissues [36, 37].

In humans there is evidence that cytokines can modulate or be modulated by body composition and insulin resistance. Firstly, we have observed that those subjects that are homozygotes for the absence of the restriction site, resulting from a guanine to adenine substitution, at position -308 of the TNF- $\alpha$ promoter, showed increased per cent fat mass and leptin concentrations and a decreased insulin sensitivity index [38]. This substitution leads to higher constitutive and inducible concentrations of transcription of the $T N F-\alpha$ gene than the wild-type allele [39]. Subjects with this mutation also showed increased body mass index on an epidemiological basis [40]. Note, this polymorphism (TNF2) is also associated with morbidity and mortality after cerebral malaria in a Gambian cohort [41], thus suggesting that a common factor is involved in metabolism and immune functions. In The Gambia, the TNF2 allele exists at a gene frequency 0.16 , implying that the TNF2 allele is maintained because heterozygotes possess an optimal TNF- $\alpha$ response against a broad range of infections. Mutations within regulatory elements of the $T N F-\alpha$ gene were not associated with an increase in the prevalence of non-insulin-dependent diabetes mellitus in one study [42]. In that report, insulin resistance was, however, not evaluated.

The differences in body composition and insulin resistance seem to be restricted to the $T N F-\alpha$ gene because polymorphisms of the $T N F-\beta$ gene are not associated with these phenotypical characteristics [43].

Secondly, obese women express approximately twofold more tumour necrosis factor receptor-2 (TNFR2) mRNA in fat tissue and approximately sixfold more soluble TNFR2 (sTNFR2) in circulation than lean control subjects [44]. Tumour necrosis factor signals through at least two known cell surface receptors (TNFRs): TNFR1 (p55) and TNFR2 (p75) $[45,46]$.The sTNFR 2 results from a proteolytic cleavage of the cell surface forms $[47,48]$ when TNF- $\alpha$ binds to its receptor and its plasma concentrations are believed to indicate previous TNF- $\alpha$ action [48]. Plasma sTNFR1 concentrations seem to be linked to insulin secretion according to our recent findings [49]. Conversely, plasma sTNFR2 concentration is proportional to insulin action. Adipose tissue expression of TNFR2 strongly correlates with BMI and the degree of insulinaemia [44]. Recently, we have found that plasma sTNFR2 concentrations were associated with insulin resistance, independently of both BMI and WHR [27], which is in line with data obtained from patients with myotonic dystrophy [50].

Plasma sTNFR2 concentrations were found to be proportional to markers of the muscle compartment such as fat-free mass and mid-arm muscle circumference [27]. As TNF- $\alpha$ is a strong inducer of TNFR2 expression in adipocytes [44] and other cell types [51], we speculated that the association between the muscle compartment and insulin resistance might be ascribed to increased production by the muscle of 
sTNFR2, leading to stabilisation of TNF- $\alpha$ homotrimers, thus resulting in insulin resistance at the level of adipocyte. These findings correlate to the thrifty genotype hypothesis. To explain the presence of Type II diabetes in all populations, it was postulated that a thrifty genotype existed that had a selection advantage as hunter-gatherers fluctuated between feast and famine [52]. The thrifty genotype in Type II diabetes could be (or contribute to) the insulin resistance seen in muscle [53]. A selective insulin resistance in muscle would have the effect of blunting the hypoglycaemia that occurs during fasting but would allow energy storage in fat and liver during feeding. Both of these features could allow hunter-gatherers to have survival advantages during periods of food shortage $[1,2]$. We suggest that both TNF- $\alpha$ and sTNFR2, whose plasma concentrations increase during exercise [21], are mediators of insulin resistance at the level of the muscle. The induction of muscle insulin resistance would allow a food-seeking behaviour and would prevent the wasting of glucose to non-vital organs, protecting the brain and the immunological system.

Thirdly, mice lacking the TNFR2 $\left(p 75^{-/-}\right)$fed a high-fat diet consistently gained less weight and had reduced insulin concentrations, an expression of improved insulin sensitivity, than wild-type mice in a recent study [54]. The concentrations of circulating leptin were modulated by TNF receptor genotype. Male $p 75^{-/}$mice fed chow had the lowest concentrations in plasma leptin at 4 and $18 \mathrm{~h}$ of fasting. High-fat fed $p 75^{-/}$were the only mice in which leptin concentrations decreased with increasing fasting time [54]. In humans, we have identified a mutation in the $T N F$ receptor 2 gene associated with higher BMI and leptin concentrations in non-diabetic subjects and diettreated Type II diabetic patients (J.-M. FernándezReal, J. Vendrell, W. Ricart, unpublished observations).

In this respect, one hypothesis that different cytokine genotypes (TNF- $\alpha$ ?, TNFR2?) possibly exist in the population as a result of the selective pressure of infectious diseases [39] is interesting. It could be that specific cytokine genotypes are beneficial in the eradication of infectious diseases but, by creating a "proinflammatory" phenotype, they predispose to chronic inflammatory diseases or to a more severe form of inflammatory disease with a worse clinical outcome, irrespective of whether the initial triggering event is an infectious agent, autoimmunity or, indeed, any cause sufficient to stimulate an inflammatory response [39].

Finally, it is possible that the nutrient-sensing and metabolic pathways have evolved in parallel to several mechanisms involved in our fight against infection. It has been hypothesised that TNF arose by divergence from a primordial recognition molecule of the innate immune system [55]. Adipocyte complement- related protein or AdipoQ is an abundant serum protein, secreted exclusively from fat cells and implicated in energy homeostasis. It is a close homologue of the complement protein $\mathrm{Clq}$ which is involved in the recognition of microbial surfaces. Studies of the structure of AdipoQ have found an unexpected homology to the tumour necrosis factor (TNF) family, firmly establishing an evolutionary link between the $\mathrm{C} 1 \mathrm{q}$ and TNF families [55]. Thus, in an evolutionary perspective, the same molecule (TNF) could have served as a recognition molecule of microbial agents, as a major factor in their eradication, as a regulator involved in signalling between the cells of the immune system and in modifying metabolism and nutrient-sensing pathways. Regarding the last aspect, recent works have suggested the existence of a TNF- $\alpha$ leptin axis, in which leptin and TNF- $\alpha$ would be in mutual interrelation. Tumour necrosis factor- $\alpha$ stimulates leptin secretion in cultured adipocytes and in obese mice and, as a feedback loop, leptin treatment in rats decreased TNF- $\alpha$ expression by $40 \%$ [56-58]. Tumour necrosis factor- $\alpha$ treatment increases serum leptin concentrations in humans [59] and plasma sTNFR1 concentration circulates in proportion to leptin [60]. The coordinated function of these two systems might be involved in controlling satiety and food intake. The TNF system might contribute to explain the large variation in circulating leptin concentrations at similar degrees of adiposity. In a recent study we observed that circulating sTNFRs concentrations were proportional to BMI and leptin in young but not older subjects and mainly in women (J.-M. Fernández-Real, J. Vendrell, W. Ricart, unpublished observations). We speculated that, when the leptin-TNF- $\alpha$ axis feedback works, the result is a lower BMI and concomitant lower leptin concentrations. In this hypothesis, subjects with a disrupted leptin - TNF- $\alpha$ axis (older people) would be prone to higher BMI and leptin, with disproportionally higher sTNFR2 concentrations.

Other relations suggest the mutual influences among nutritional factors, the immune system and insulin resistance. In this sense, the production of TNF$\alpha$ by mice, in response to endotoxin, is suppressed by desferrioxamine (an iron chelator) [61] showing the interaction between iron status and immune function. We have found that serum ferritin concentrations, thought to be influenced by iron availability and TNF- $\alpha$ [62], are directly correlated with insulin resistance in humans [63]. That genetics influence these interactions is indicated by mutations usually associated with hereditary haemochromatosis being overrepresented in our cohort of Type II diabetic patients [64]. 


\section{Insulin resistance and deregulation of the innate immune system as a body's response to chronic tissue injury}

Atherosclerosis has been viewed as a chronic inflammatory disease that develops in response to some metabolic, physical, infectious and environmental process. In the last years, it has become evident that inflammation and atherosclerosis are closely associated and it is possible that acute ischaemic events reflect exacerbation of a chronic inflammatory state. Human atherosclerotic lesions have been found to contain IL-1 mRNA [65] and TNF [66, 67]. This is of potential importance in understanding some of the physiopathologic mechanisms of atherosclerosis because early accumulation of monocytes and lymphocytes in the aortic intima with cytokine release could be essential in the development of the disease.

The accumulation of cholesteryl esters in macrophages exposed to LDL is associated with increased synthesis and release of TNF- $\alpha$ [68-70]. Increased secretion of TNF has been observed in hypercholesterolaemic rabbits [68] and in LDL-receptor knockout mice, in which plasma TNF- $\alpha$ concentrations are increased in parallel with LDL-cholesterol [69]. Atherogenic diets enhance endotoxin-stimulated $T N F-\alpha$ gene expression in rabbit aortae [70]. Furthermore, knockout mice for TNFR1 gene show accelerated atherosclerosis [71]. Notably, we have found that plasma concentrations of the soluble fractions of tumour necrosis factor receptor 1 and 2 (TNFR1 and TNFR2) are proportional to total and LDL cholesterol concentrations [72]. Those of TNFR2 were inversely correlated with HDL-C concentration.

The potential contribution of non-traditional risk factors, such as infectious agents, has recently gathered considerable interest [73-79]. It cannot be excluded that macrophage infiltration in response to a chronic arterial infection might in some cases instigate lesion formation [78]. Substantial seroepidemiologic and some experimental evidence links Chlamydia pneumoniae with the pathogenesis and natural history of atherosclerosis [77]. Chlamydia has been found to induce production of TNF- $\alpha$, which inhibits the action of lipoprotein lipase, leading to changed lipid metabolism, accumulation of serum triglycerides and a decrease in serum high density lipoprotein cholesterol (HDL-C). Lipopolysaccharide, a bacterial component, binds in human serum to both HDL-C and low density lipoprotein cholesterol (LDL-C) and makes LDL-C immunogenic or toxic to endothelial cells. Local infections with agents such as $C$. pneumoniae have been suggested to potentiate the evolution of pre-existing atheroma, to which macrophages have already been recruited by, e.g. hypercholesterolaemia [77, 78], finally leading to plaque instability and rupture.

Many subjects with a long-term stress response have the insulin resistance syndrome [4]. Ischaemic

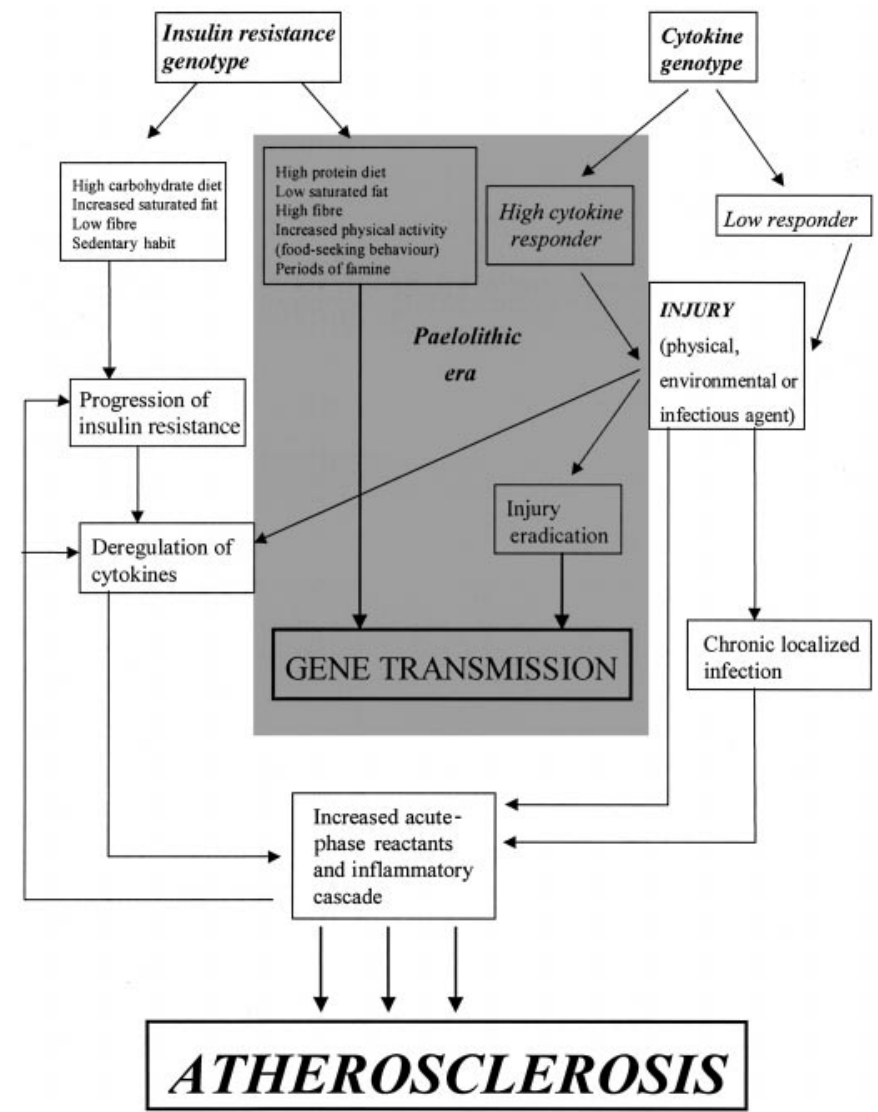

Fig. 1. see text

heart disease and insulin resistance are thought to share physiopathologic mechanisms [10]. Thus, the association among $\mathrm{C}$ reactive protein, leucocyte count, several other reactants and ischaemic heart disease [80] might be interpreted as insulin resistance being the body's response to chronic tissue infection and thus a by-product of an inflammatory cascade triggered by environmental agents.

\section{Conclusion}

Our hypothesis is illustrated and summarized in Figure 1. An insulin resistance genotype or a cytokine genotype adapted to the environment are beneficial in the presence of a low saturated fat diet, with high fibre and high protein, increased physical activity and frequent periods of famine. Any accidental injury is succesfully eradicated and the consequence is gene transmission. In the absence of these ambient conditions, a progressive insulin resistance can ensue. With increased age and different injuries, the insulin resistance progresses, leading, in a vicious cycle, to amplification of the inflammatory cascade, finally resulting in atherosclerosis. A low cytokine responder will eradicate any injury less succesfully. Chronic intracellular infections (Chlamydia?, Helicobacter?) 
will be more probable in this situation, eventually leading to atherosclerosis if the eradication is not complete. For our ancestors, the advantages of a high cytokine responder or moderate insulin resistance overcame the possible inconveniences of atherosclerosis. With a life expectancy of 35 years, the price to pay was very low. It cannot in the terms of classic evolutionary science be named, "genetic maladaptation", because it does not affect differential fertility. We think that, perhaps, these "maladaptations" are "good adaptations" to the environment, in our ancestral fight with infectious disease, injury and wound repair or "maladaptations" of the actual lifestyle to our genome.

\section{More arguments}

Differences in the frequency of diabetes between populations are enormous. In Europe, the frequency of Type II diabetes is one of the lowest in the world despite increasing obesity. Very recently it has been suggested that, because most diabetogenes are recessive, the greater the genetic heterogeneity of a population, the lower the chances of homozygosity, thus explaining this "European paradox" [81]. In European history there has been a much higher degree of interbreeding than in almost any other area in the world [81]. On the other hand, in the presence of numerous infectious diseases, different alleles, protecting against individual pathogens, could make heterozygosity advantageous overall [82]. Hence, genetic diversity might have contributed, simultaneously, to defence against infection and to the lower prevalence of Type II diabetes mellitus and its predisposing condition, insulin resistance, among Europeans.

Acknowledgements. We are most grateful to Drs J. Vendrell and R. Casamitjana for their encouragement and fruitful collaboration.

\section{References}

1. Eaton SB, Konner M (1985) Paleolithic nutrition. A consideration of its nature and current implications. N Engl J Med 312: 283-289

2. Eaton SB, Konner M, Shostak M (1988) Stone agers in the fast lane: chronic degenerative diseases in evolutionary perspective. Am J Med 84: 739-749

3. Wendorf M, Goldfine ID (1991) Archaeology of NIDDM. Excavation of the "thrifty" genotype. Diabetes 40: 161-165

4. Pickup JC, Crook MA (1998) Is type II diabetes mellitus a disease of the innate immune system? Diabetologia 41: 1241-1248

5. Grimble R (1992) Dietary manipulation of the inflammatory response. Proc Nutri Soc 51: 285-294

6. Kauffman CA, Jones PG, Kluger MJ (1986) Fever and malnutrition endogenous pyrogen/interleukin-1 in malnourished patients. Am J Clin Nutr 44: 449-452
7. Vaisman N, Schattner A, Hahn T (1989) Tumor necrosis factor production during starvation. Am J Med 87: 115

8. Murray MJ, Murray AB (1980) Cachexia: a "last ditch" mechanism of host defence? J R Coll Physicians Lond 14: 197-199

9. Grimble RF (1998) Nutritional modulation of cytokine biology. Nutrition 14: 634-640

10. Reaven GM (1988) Role of insulin resistance in human disease. Diabetes 37: 1595-1607

11. Crook MA, Tutt P, Pickup JC (1993) Elevated serum sialic acid concentration in non-insulin-dependent diabetes and its relationship to blood pressure and retinopathy. Diabetes Care 16: 57-60

12. Crook MA, Tutt P, Simpson H, Pickup JC (1993) Serum sialic acid and acute phase proteins in Type 1 and 2 diabetes. Clin Chim Acta 219: 131-138

13. Campos SP, Baumann H (1992) Insulin is a prominent modulator of the cytokine-stimulated expression of acuteplasma protein genes. Mol Cell Biol 12: 1789-1797

14. Fernández Real JM, Grasa M, Casamitjana R, Pugeat M, Barret C, Ricart W (1999) Plasma total and glycosylated corticosteroid binding globulin (CBG) levels are associated with insulin secretion. J Clin Endocrinol Metab (in press)

15. Baumann H, Gauldie J (1994) The acute phase response. Immunol Today 15: 74-80

16. Nieman DC (1997) Immune response to heavy exertion. J Appl Physiol 82: 1385-1394

17. Koffler M, Kisch ES (1996) Starvation diet and very-lowcalorie diets may induce insulin resistance and overt diabetes. J Diabetes Complications 10: 109-112

18. Holness MJ, Sugden MC (1999) Antecedent protein restriction exarcebates development of impaired insulin action after high-fat feeding. Am J Physiol 276:E85-E93

19. Ravelli AC, van der Meulen JH, Michels RP et al. (1998) Glucose tolerance in adults after prenatal exposure to famine. Lancet 351: 173-177

20. Tuominen JA, Ebeling P, Bourey R et al. (1996) Postmarathon paradox: insulin resistance in the face of glycogen depletion. Am J Physiol 270:E336-E343

21. Pedersen BK, Nieman DC (1998) Exercise immunology: integration and regulation. Immunol Today 19: 204-206

22. Nieman DC, Nehlsen-Cannarella SL, Fagoaga OR et al. (1998) Influence of mode and carbohydrate on the cytokine response to heavy exertion. Med Sci Sports Exerc 30: 671-678

23. Fernández-Real JM, Ricart W, Casamitjana R (1997) Lower cortisol levels after oral glucose in subjects with insulin resistance and abdominal obesity. Clin Endocrinol (Oxf) 47: 583-588

24. Paolisso G, Rizzo MR, Mazziotti G et al. (1998) Advancing age and insulin resistance: role of plasma tumor necrosis factor-alpha. Am J Physiol 275 (2 Pt 1):E294-E299

25. Caswell M, Pike LA, Bull BS, Stuart J (1993) Effect of age on tests of the acute-phase response. Arch Pathol Lab Med 117: 906-910

26. Fagiolo U, Cossarizza A, Scala E (1993) Increased cytokine production in mononuclear cells of healthy elderly people. Eur J Immunol 23: 2375-2378

27. Fernández-Real JM, Broch M, Ricart Wet al. (1998) Plasma Levels of the Soluble Fraction of Tumor Necrosis Factor Receptor 2 and Insulin Resistance. Diabetes 47: 1757-1762

28. Hotamisligil GS, Shargill NS, Spiegelman BM (1993) Adipose expression of tumor necrosis factor-alpha: direct role in obesity-linked insulin resistance. Science 259: 87-91

29. Hotamisligil GS, Budavari A, Murray D, Spiegelman BM (1994) Reduced tyrosine kinase activity of the insulin receptor in obesity-diabetes. J Clin Invest 94: 1543-1549 
30. Hotamisligil GS, Peraldi P, Budavari A, Ellis R, White MF, Spiegelman BM (1996) IRS-1-mediated inhibition of insulin receptor tyrosine kinase activity in TNF-alpha- and obesity-induced insulin resistance. Science 271: 665-668

31. Hotamisligil GS, Spiegelman BM (1994) Tumor Necrosis Factor a: A Key Component of the Obesity-Diabetes Link. Diabetes 43: 1271-1278

32. Kern PA, Saghizadeh M, Ong JM, Bosch RJ, Deem R, Simsolo RB (1995) The expression of Tumor Necrosis Factor in Human Adipose Tisssue. Regulation by Obesity, Weight Loss, and Relationship to Lipoprotein Lipase. J Clin Invest 95: 2111-2119

33. Hotamisligil GS, Arner P, Caro JF, Atkinson RL, Spiegelman BM (1995) Increased Adipose Tissue Expression of Tumor Necrosis Factor- $\alpha$ in Human Obesity and Insulin Resistance. J Clin Invest 95: 2409-2415

34. Saghizadeh M, Ong JM, Garvey WT, Henry RR, Kern PA (1996) The Expression of TNFa by Human Muscle. Relationship to Insulin Resistance. J Clin Invest 97: 1111-1116

35. Ofei F, Hurel S, Newkirk J, Sopwith M, Taylor R (1996) Effect of an Engineered Human Anti-TNF- $\alpha$ Antibody (CDP571) on Insulin Sensitivity and Glycemic Control in Patients with NIDDM. Diabetes 45: 881-885

36. Ventre J, Doebber T, Wu M et al. (1997) Targeted disruption of the tumor necrosis factor- $\alpha$ gene. Metabolic consequences in obese and nonobese mice. Diabetes 46: 1526-1531

37. Uysal KT, Wiesbrock SM, Marino MW, Hotamisligil GS (1997) Protection from obesity-induced insulin resistance in mice lacking TNF- $\alpha$ function. Nature 389: 610-614

38. Fernández-Real JM, Gutierrez C, Ricart W et al. (1997) The TNF- $\alpha$ Nco I polymorphism influences the relationship among insulin resistance, percent body fat and increased serum leptin levels. Diabetes 46: 1468-1472

39. Wilson AG, Symons JA, McDowell TL, McDevitt HO, Duff GW (1997) Effects of a polymorphism in the human tumour necrosis factor alfa promoter on transcriptional activation. Proc Natl Acad Sci USA 94: 3195-3199

40. Herrmann SM, Ricard S, Nicaud V et al. (1998) Polymorphisms of the tumour necrosis factor- $\alpha$ gene, coronary heart disease and obesity. Eur J Clin Invest 28: 59-66

41. McGuire W, Hill VS, Allsopp EM, Greenwood BM, Kwaitkowski D (1994) Variation in the TNF- $\alpha$ promoter region associated with susceptibility to cerebral malaria. Nature 371: 508-511

42. Hamann A, Mantzoros C, Vidal-Puig A, Flier JS (1995) Genetic variability in the TNF-alpha promoter is not associated with type II diabetes mellitus (NIDDM). Biochem Biophys Res Commun 211: 833-839

43. Fernández-Real JM, Gutierrez C, Ricart W et al. (1997) A TNF- $\beta$ gene Nco I polymorphism is not associated with hypertrygliceridemia or insulin resistance in lean and obese subjects. Biochem Biophys Res Commun 236: 829-832

44. Hotamisligil GS, Arner P, Atkinson RL, Spiegelman BM (1997) Differential regulation of the p80 Tumor Necrosis Factor Receptor in human obesity and insulin resistance. Diabetes 46: 451-455

45. Tartaglia LA, Goeddel DV (1992) Two TNF receptors. Immunol Today 13: 151-153

46. Smith CA, Farrah T, Goodwin RG (1994) The TNF receptor superfamily of cellular and viral proteins: activation, costimulation and death. Cell 76: 959-962

47. Nophar Y, Kemper O, Brakebusch C et al. (1990) Soluble forms of tumor necrosis factors (TNF-Rs). The cDNA for the type I TNF-R, cloned using amino acid sequence data of its soluble form, encodes both the cell surface and a soluble form of the receptor. EMBO J 9: 3269-3278
48. Aderka D, Engelmann H, Maor Y, Brakebusch C, Wallach D (1992) Stabilization of the bioactivity of tumor necrosis factor by its soluble receptors. J Exp Med 175: 323-329

49. Fernández-Real JM, Gutierrez C, Broch M, Casamitjana R, Vendrell J, Ricart W (1999) The Insulin response to intravenous glucose correlates with plasma levels of the tumor necrosis factor receptor-1. Diabetes Care 22: 868-870

50. Fernández-Real JM, Molina A, Broch M et al. (1999) The TNF system activity is associated with insulin resistance and dyslipidemia in myotonic dystrophy. Diabetes 48: 1108-1112

51. Winzen R, Wallach D, Kemper O, Resch K, Holtmann H (1993) Selective upregulation of the 75-kDa tumor necrosis (TNF) receptor and its $\mathrm{mRNA}$ by TNF and IL-1. J Immunol 150: 4346-4353

52. Neel JV (1962) Diabetes mellitus: a "thrifty" genotype rendered detrimental by "progress". Am J Hum Genet 14: 353-362

53. Reaven GM (1998) Hypothesis: muscle insulin resistance is the ("not-so") thrifty genotype. Diabetologia 41: 482-484

54. Schreyer SA, Chua SC, LeBoeuf RC (1998) Obesity and diabetes in TNF-alfa receptor-deficient mice. J Clin Invest 102: 402-411

55. Shapiro L, Scherer PE (1998) The crystal structure of a complement-1 q family protein suggests an evolutionary link to tumor necrosis factor. Curr Biol 8: 335-338

56. Grunfeld C, Zhao C, Fuller J et al. (1996) Endotoxin and Cytokines Induce Expression of Leptin, the ob Gene Product, in Hamsters. A Role for Leptin in the Anorexia of Infection. J Clin Invest 97: 2152-2157

57. Kirchgessner TG, Uysal KT, Wiesbrock SM, Marino MW, Hotamisligil GS (1997) Tumor necrosis factor- $\alpha$ contributes to obesity-related hyperleptinemia by regulating leptin release from adipocytes. J Clin Invest 100: 2777-2782

58. Qian H, Hausman GJ, Compton MM, Azain MJ, Hartzell DL, Baile CA (1998) Leptin regulation of peroxisome proliferator-activated receptor-gamma, tumor necrosis factor, and uncoupling protein-2 expression in adipose tissues. Biochem Biophys Res Commun 246: 660-667

59. Zumbach MS, Boehme MW, Wahl P, Stremmel W, Ziegler R, Nawroth PP (1997) Tumor necrosis factor increases serum leptin levels in humans. J Clin Endocrinol Metab 82: 4080-4082

60. Mantzoros CS, Moschos S, Avramopoulos I et al. (1997) Leptin concentrations in relation to body mass index and the tumor necrosis factor- $\alpha$ system in humans. J Clin Endocrinol Metab 82: 3408-3413

61. Chaudhri G, Clark IA (1989) Reactive oxygen species facilitate the in vitro and in vivo lipopolysaccharide-induced release of tumor necrosis factor. J Immunol 143: 1290-1294

62. Miller LL, Miller SC, Torti SV, Tsuji Y, Torti FM (1991) Iron-independent induction of ferritin $\mathrm{H}$ chain by tumor necrosis factor. Proc Natl Acad Sci USA 88: 4946-4950

63. Fernández-Real JM, Ricart W, Arroyo E et al. (1998) Serum ferritin as a component of the Insulin Resistance syndrome. Diabetes Care 21: 62-68

64. Fernández-Real JM, Vendrell J, Baiget M, Gimferrer E, Ricart W (1999) C282Y and H63D mutations of the hemochromatosis candidate gene in Type II diabetes. Diabetes Care 22: 525-526

65. Clinton SK, Fleet JC, Loppnow H et al. (1991) Interleukin1 gene expression in rabbit vascular tissue in vivo. Am J Pathol 138: 1005-1014

66. Barath P, Fishbein MC, Cao J, Berenson J, Helfant RH, Forrester JS (1989) Detection and localization of TNF in human atheroma. Am J Cardiol 21: 1241-1251 
67. Kaartinen M, Penttilä A, Kovanen P (1996) Mast cells in rupture-prone areas of human coronary atheromas produce and store TNF- $\alpha$. Circulation 94: 2787-2792

68. Brito BE, Romano EL, Grunfeld C (1995) Increase lipopolysaccharide-induced tumour necrosis factor levels and death in hypercholesterolaemic rabbits. Clin Exp Immunol 101: 357-361

69. Henninger DD, Gerritsen ME, Granger DN (1997) Lowdensity lipoprotein receptor knockout mice exhibit exaggerated microvascular responses to inflammatory stimuli. Circ Res 81: 274-281

70. Fleet JC, Clinton SK, Salomon RN, Loppnow H, Libby P (1992) Atherogenic diets enhance endotoxin-stimulated interleukin-1 and tumor necrosis factor gene expression in rabbit aortae. J Nutr 122: 294-305

71. Schreyer SA, Peschon JJ, LeBoeuf RC (1996) Accelerated atherosclerosis in mice lacking tumor necrosis factor receptor p55. J Biol Chem 271: 26174-26178

72. Fernández-Real JM, Gutierrez C, Ricart W et al. (1999) Plasma levels of the soluble fraction of tumor necrosis factor- $\alpha$ receptors 1 and 2 are independent determinants of total and LDL-Cholesterol concentrations in healthy subjects. Atherosclerosis (in press)

73. Saikku P, Leinonen M, Mattila K et al. (1988) Serologic evidence of an association of a novel Chlamydia, TWAR, with coronary artery disease and acute myocardial infarction. Lancet 331:983-986
74. Patel P, Mendall MA, Carrington D et al. (1995) Association of Helicobacter pylori and Chlamydia pneumoniae infections with coronary heart disease and cardiovascular risk factors. BMJ 311: 711-714

75. Miettinen H, Lebto S, Saikku P et al. (1996) Association of Chlamydia pneumonia and coronary heart disease events in non-insulin-dependent diabetic and non-diabetic subjects in Finland. Eur Heart J 17: 682-688

76. Gupta S, Camm AJ (1997) Chlamydia pneumoniae and coronary heart disease. BMJ 314: 1778-1779

77. Mehta JL, Saldeen TG, Rand K (1998) Interactive role of infection, inflammation and traditional risk factors in atherosclerosis and coronary artery disease. J Am Coll Cardiol 31: $1217-1225$

78. Kol A, Sukhova GK, Lichtman AH, Libby P (1998) Chlamydial heat shock protein 60 localizes in human atheroma and regulates macrophage tumor necrosis factor- $\alpha$ and matrix metalloproteinase expression. Circulation 98: 300-307

79. Ross R (1999) Atherosclerosis - an inflammatory disease. N Engl J Med 340: 115-126

80. Danesh J, Collins R, Appleby P, Peto R (1998) Association of fibrinogen, C-reactive protein, albumin, or leukocyte count with coronary heart disease: meta-analyses of prospective studies. JAMA 279: 1477-1482

81. Lev-Ran A (1999) Thrifty genotype: how applicable is it to obesity and Type II diabetes? Diabetes Rev 7: 1-22

82. Hill AVS (1999) Defence by diversity. Nature 398: 668-669 